\title{
CT-undersøkelse ved cerebral sinusvenetrombose
}
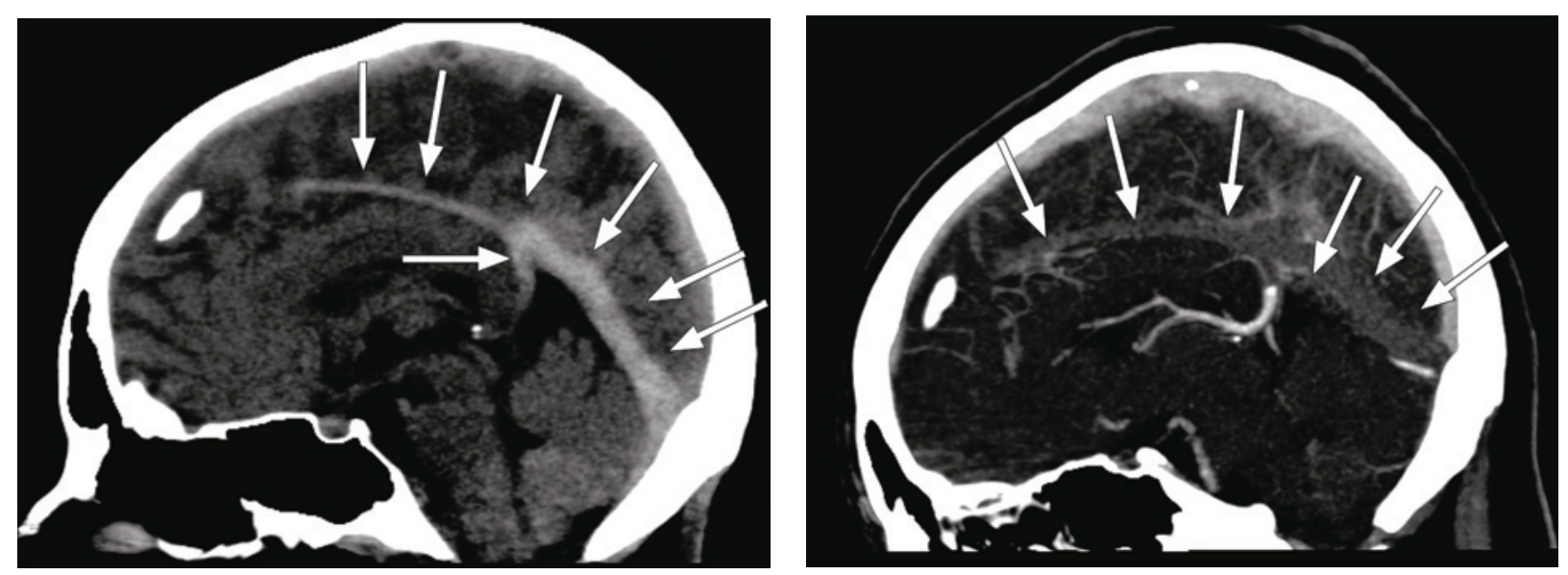

En ikke-røykende kvinne i 20-årene med kjent cøliaki søkte lege etter fire dager med tiltakende pulserende bifrontal og retrobulbær hodepine. Innleggelsesdagen opplevde hun markant smerteøkning og kvalme, med tydelig hodepineaggravasjon i tilslutning til oppkast. Det var ingen kjent migrene i familien. Utover p-piller brukte hun ingen faste medisiner.

Nevrologisk og oftalmologisk status var normal.

Biokjemiske prøver viste forhøyet $\mathrm{D}$-dimer $0,78 \mathrm{mg} / \mathrm{l}(0,0-0,4 \mathrm{mg} / \mathrm{l})$. Cerebral CT viste forstørret og hyperdens sinus sagittalis inferior, sinus rectus og vena Galeni (bildet til venstre). Funnet ga sterk mistanke om cerebral sinusvenetrombose. Dette ble bekreftet ved kontrastforsterket CT-venografi, hvor man kunne se manglende kontrastfylling av de samme strukturene (bildet til høyre). Antikonsepsjonmidlet ble seponert og pasienten behandlet med lavmolekylært heparin og warfarin. Etter seks måneders behandling viste MR-undersøkelse kun sparsomme resttromber.

Cerebral sinusvenetrombose er en relativt sjelden tilstand som man kan mistenke hos alle med nyoppstått uforklarlig hodepine. Forekomsten er høyest hos kvinner. Patogenesen er ufullstendig forstått, men trombofiliutredning er påkrevd. P-pillebruk medfører 16 ganger økt risiko, og subakutt hodepine er det vanligste debutsymptomet (1).
Komplikasjoner i form av venøse, gjerne hemoragiske, infarkter lokalisert kortikalt kan føre til epileptiske anfall eller lateraliserende fokalnevrologiske utfall.

Kontrastforsterket CT-undersøkelse kan avdekke «empty delta $(\Delta)$ sign», der tromben ses som en lavtett triangulær forandring omgitt av den røntgentette hvite kontrasten. Hos vår pasient så man altså høy tetthet allerede på native serier. Dette fenomenet omtales $\mathrm{i}$ litteraturen som «cord sign» og skyldes trombose (2). Et tilsvarende fenomen, kalt «hyperdense artery sign», kan ses ved akutt iskemisk hjerneslag.

Pasienten har gitt samtykke til at artikkelen blir publisert.

\section{Johannes Sverre Willumsen}

johannes.sverre.willumsen@helse-mr.no

Nevrologisk avdeling

Molde sjukehus

\section{Therese Schjørlien}

Nevrologisk avdeling

Molde sjukehus

\section{Thomas Nygaard}

Kirurgisk avdeling

Molde sjukehus

\section{Kristoffer Lundesgaard*}

Radiologisk avdeling

Molde sjukehus

* Nåværende arbeidssted:

Oslo universitetssykehus, Rikshospitalet
Johannes Sverre Willumsen (f. 1987) er konstituert overlege.

Forfatter har fylt ut ICMJE-skjemaet og oppgir ingen interessekonflikter.

Therese Schjørlien (f. 1983) er lege i spesialisering.

Forfatter har fylt ut ICMJE-skjemaet og oppgir ingen interessekonflikter.

Thomas Nygaard (f. 1984) er lege i spesialisering.

Forfatter har fylt ut ICMJE-skjemaet og oppgir ingen interessekonflikter.

Kristoffer Lundesgaard (f. 1980) er spesialist i radiologi og overlege.

Forfatter har fylt ut ICMJE-skjemaet og oppgir ingen interessekonflikter.

Litteratur

1. Johnsen HJ, Vorhaug A, Kvistad KA. Cerebral venetrombose - diagnostikk og behandling. Tidsskr Nor Lægeforen 2007; 127: 1069-73.

2. Zeina AR, Kassem E, Klein A et al. Hyperdense cerebral sinus vein thrombosis on computed tomography. West J Emerg Med 2010; 11: 217.

Mottatt 24.8. 2016, første revisjon innsendt 12.12. 2016, godkjent 22.12. 2016. Redaktør: Liv-Ellen Vangsnes. 